\title{
Anti-HCV seroprevalence in pregnant women in France
}

\author{
F Roudot-Thoraval, J-M Pawlotsky, L Deforges, P-P Girollet, D Dhumeaux
}

\begin{abstract}
In a study designed to assess the prevalence of antibodies to hepatitis C virus (HCV) in pregnant women, antiHCV positivity in French pregnant women was twice as high as that found in French blood donors. Positive ELISA 2 results were confirmed by positive RIBA 2 in most subjects, and seven of nine RIBA 2 positive patients also tested positive for HCV-RNA by PCR. High rates of antiHCV positivity were seen among immigrant pregnant women, partly because of false positive results with ELISA 2. RIBA 2 results suggested that the prevalence of HCV infection was not any higher in immigrant compared with French pregnant women.
\end{abstract}

(Gut 1993; supplement: S55-S56)

The aim of this study was to assess the seroprevalence of antibodies to hepatitis C virus (anti-HCV) in pregnant women who represent a healthy population and in a population unselected for risk factors of transmitted diseases.

\footnotetext{
Départements

d'Epidémiologie and

d'Hépatologie,

Service de

Bactériologie-Virologie,

Hôpital Henri Mondor,

Créteil, France

F Roudot-Thoraval

J-M Pawlotsky

L Deforges

P-P Girollet

D Dhumeaux

Correspondence to:

Dr F Roudot-Thoraval,

Département

d'Epidémiologie,

Département d'Hépatologie,

Hôpital Henri Mondor,

Créteil, France.
}

TABLE I Anti-HCV positivity (ELISA 2) according to geographical origin

\begin{tabular}{lrrl}
\hline Origin & $\begin{array}{l}\text { Women } \\
\text { studied } \\
(n)\end{array}$ & $\begin{array}{l}\text { Anti-HCV } \\
\text { positive } \\
(n)\end{array}$ & $\begin{array}{l}\text { Prevalence of } \\
\text { anti-HCV } \\
(\%)\end{array}$ \\
\hline French & 1614 & 25 & $1 \cdot 55$ \\
$\quad$ Mainland & 1471 & 25 & $1 \cdot 70$ \\
Overseas territories & 143 & 0 & 0 \\
Immigrant & 753 & 16 & $2 \cdot 13$ \\
South Europe & 101 & 1 & $0 \cdot 99$ \\
North Africa & 301 & 5 & $1 \cdot 66$ \\
West Africa & 246 & 10 & $4 \cdot 07$ \\
Asia & 105 & 0 & 0 \\
\hline
\end{tabular}

TABLE II Comparison of ELISA 2, RIBA 2, and polymerase chain reactions (PCR) results in French and immigrant pregnant women

\begin{tabular}{llll}
\hline $\begin{array}{l}\text { Women studied } \\
(n)\end{array}$ & $\begin{array}{l}\text { ELISA 2 positive } \\
(\%)\end{array}$ & $\begin{array}{l}\text { RIBA 2 positive } \\
(\%)\end{array}$ & $\begin{array}{l}\text { HCV-RNA } \\
\text { positive }\end{array}$ \\
\hline French $(1614)$ & $25(1.55)$ & $16(0.99)$ & $7 / 15^{\star}$ \\
Immigrant (753) & $16(2 \cdot 13)$ & $8(1.06)$ & $1 / 6 \dagger$ \\
\hline
\end{tabular}

*Nine of 15 had positive RIBA 2; all seven PCR positive women had positive RIBA 2.

tThree of six had positive RIBA 2; the only PCR positive woman had positive RIBA 2.

TABLE III Risk factors associated with anti-HCV positivity (ELISA 2)

\begin{tabular}{lclcc}
\hline Anti-HCV antibodies & $\begin{array}{c}\text { Positive } \\
(n=41)\end{array}$ & & $\begin{array}{c}\text { Negative } \\
(n=2326)\end{array}$ & $\begin{array}{c}\text { Positive } \\
\text { women }\end{array}$ \\
\hline Previous intravenous drug addiction & $24 \cdot 4 \%$ & $\mathrm{p}<0.001$ & $0 \cdot 3 \%$ & $59 \%$ \\
History of transfusion & $22 \cdot 0 \%$ & $\mathrm{p}<0.01$ & $4 \cdot 6 \%$ & $8 \%$ \\
Professional exposure & $7 \cdot 3 \%$ & $\mathrm{NS}$ & $5 \cdot 8 \%$ & $2 \%$ \\
Previous hepatitis & $26 \cdot 8 \%$ & $\mathrm{p}<0.001$ & $3 \cdot 4 \%$ & $12 \%$ \\
At least one risk factor & $58 \cdot 5 \%$ & $\mathrm{p}<0.001$ & $10 \cdot 2 \%$ & $9 \%$ \\
\hline
\end{tabular}

\section{Methods}

A population of 2367 pregnant women was studied, and subdivided according to geographical origin. All were questioned about their exposure to risk factors for $\mathrm{HCV}$. The presence of anti-HCV antibodies in serum was detected using the second generation ELISA (ELISA 2) and second generation RIBA (RIBA 2). Polymerase chain reaction was used to test for HCV-RNA in small numbers of subjects. Fisher's test of exact probability was used in a statistical comparison of risk factors in the two groups.

\section{Results}

The prevalence of anti-HCV positivity (ELISA 2) according to geographical origin of the pregnant women is shown in Table I. In French pregnant women, the prevalence of anti-HCV was found to be twice as high as that found in French blood donors $(1.55 \% v 0.7 \%$ respectively, $\mathrm{p}<0.001)$. Among immigrant populations, the highest anti-HCV seropositivity rate was found in those from west Africa $(4 \cdot 07 \%)$.

When the women were tested with RIBA 2, the seropositivity rate in French women fell from $1.55-0.99 \%$, and in immigrant women from $2 \cdot 13-1 \cdot 06 \%$, bringing the prevalence in the two populations to a similar value (Table II). This suggests a high number of falsepositive results on ELISA 2 in the immigrant population. All seven French women and the one immigrant woman who tested positive for HCV-RNA on polymerase chain reaction were also RIBA 2 positive. Analysis according to risk factors for $\mathrm{HCV}$ infection showed a significant association between anti-HCV positivity (ELISA 2) and previous intravenous drug addiction, history of transfusion, and previous hepatitis ( $p<0.001$ in each case) (Table III). Comparison between French and immigrant populations showed considerable variations in the proportions of subjects with various risk factors, but there were no statistically significant differences (Figure).

When considering only women with positive RIBA 2 results, risk factors for $\mathrm{HCV}$ infection were identified in a similarly high proportion in French and immigrant women $(81 \%$ and $75 \%$, respectively).

\section{Conclusions}

In French pregnant women, the prevalence of anti-HCV is twice as high as that in blood donors and probably provides a better estimate of the actual prevalence of these antibodies in 


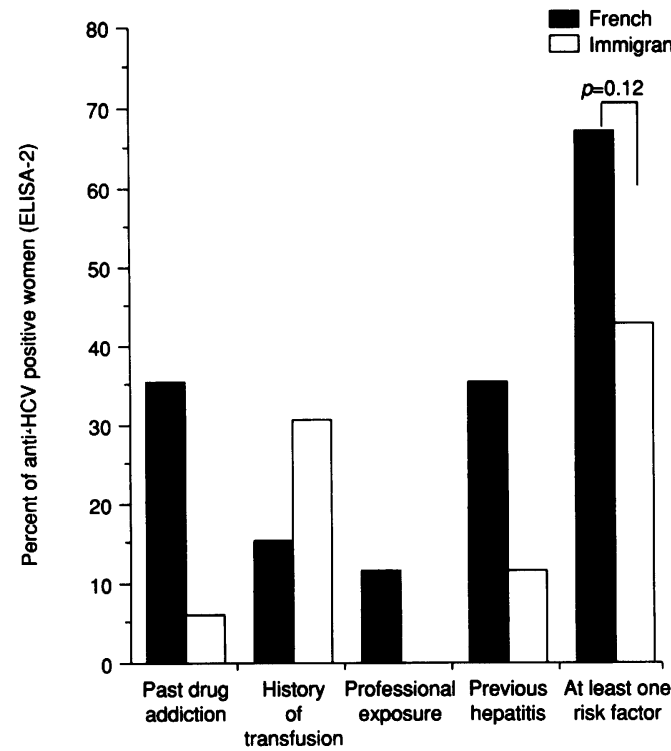

France. Positive ELISA 2 results were confirmed by positive RIBA 2 in most subjects, and seven of nine RIBA 2 positive subjects tested on polymerase chain reaction were also positive for HCV-RNA. Among immigrant pregnant women, high rates of anti-HCV positivity were seen with the ELISA 2 test, partly because of false-positive results. Based on RIBA 2 results, the prevalence of $\mathrm{HCV}$ infection does not appear to be any higher in these women than in French women.

Figure Risk factors for HCV infection in French and immigrant pregnant women. 